\title{
MSN/ALK Fusion Protein
}

National Cancer Institute

\section{Source}

National Cancer Institute. MSN/ALK Fusion Protein. NCI Thesaurus. Code C101060.

A fusion protein encoded by the MSN/ALK fusion gene. This protein is comprised of most of the moesin protein, including the band 4.1 region, fused to the cytoplasmic domain of the ALK tyrosine kinase receptor protein, including the tyrosine kinase domain. 